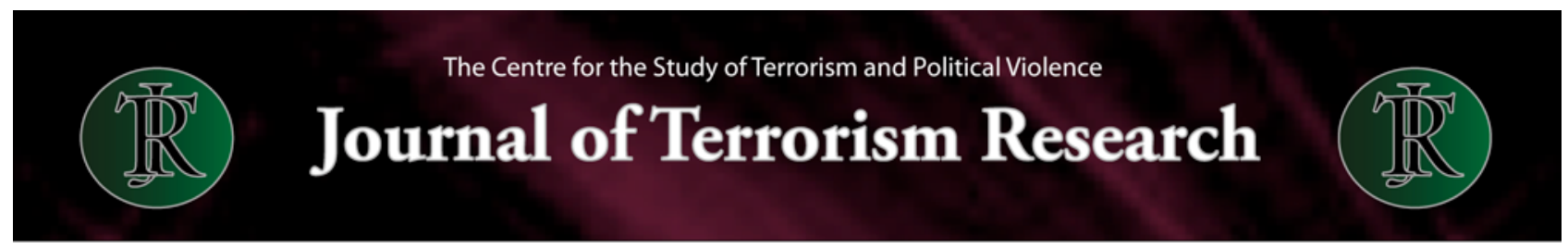

\title{
Lashkar-e-Taiba of Pakistan: An India Centric Threat Projection
}

\author{
by Saroj Kumar Rath
}

\begin{abstract}
Within a year of the Mumbai attacks by Lashkar-e-Taiba (LeT), the public outrage that many thought would usher in a political groundswell for a firmer government response, has dissipated. Almost all the political figures who resigned as a result of the attacks either back in their old jobs or promoted to other plumb posts. After a brief hiatus, bombings by LeT and/or its affiliates resumed in cities like Mumbai, Delhi, Pune, Varanasi and Srinagar. Total casualty including leftwing extremism related death since Mumbai attacks as per the South Asia Terrorism Portals is more than 5000. India's post-Mumbai public appraisal and official introspection is no match to the response of the US after September 11. India's lackluster appreciation of the impending danger could be undersood from the fact that, while the US government has commissioned atleast a dozen of official studies on LeT after the Mumbai attacks, India government commissioned none. The LeT is gradually growing from strength to strengh by encompassing the role of a political pressure group under the guise of Difa-e-Pakistan. But India is blind to the development and poised to the danger unfolding in its western neighbour.
\end{abstract}

Keywords: Lashkar-e-Taiba, Difa-e-Pakistan, India, Pakistan, Future Security.

\section{The Gathering Cloud}

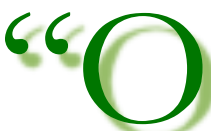

n May 10, 2011, exactly a week after the US Navy SEALs killed Osama bin Laden in a raid on a compound near Pakistan's top army training school Kakul Academy in Abbottabad, the US Joint Chief of Staff Admiral Mike Mullen received an unsigned, undated secret memo from Pakistan. Hussain Haqqani, then Pakistani Ambassador sent the memo through the secret intermediaries of US businessman Mansoor Ijaz to Adm. Mullen after the alleged approval of President Asif Ali Zardari[1]. The document, which sought Adm. Mullen's intervention in the affair of Pakistan, reveals interesting facts about Mumbai terror attacks. The memo indicated that the Zardari government suspected active involvement of the shadowy S-Wing of Inter Services Intelligence (ISI) in the Mumbai attacks and expressed helplessness in bringing the perpetrators into justice[2]. Admitting the role of ISI in the Mumbai attacks and proposing a new national security team the memo said, 'We are prepared to bring all perpetrators of Pakistani origin to account for the 2008 Mumbai attacks, whether outside government or inside any part of the government, including its intelligence agencies'[3]. Earlier, Pakistan government has admitted the role of LeT and Pakistani citizen in the Mumbai attacks[4]. The secret memo was the first official admission by Pakistan about the involvement of ISI in the Mumbai conspiracy.

Not only this, the memo provides a rare glimpse into the inner sanctum of the shadowy S-Wing of the ISI, whose relations with the LeT is robust. The S-Wing of ISI has been responsible for many attacks and it is said that this wing is dedicated to promoting the dubious agenda of a narrow group of nationalists who believe only they can protect Pakistan's territorial integrity[5]. Such blatant admission is a sign of ongoing as well as impending ISI-LeT sponsored danger against India. The 


\section{Journal of Terrorism Research}

S-Wing provides military support and intelligence logistics to groups like the LeT as the ISI embodies the scourge of radicalism that has become a cornerstone of Pakistan's foreign policy[6].

The availability of literature on LeT is abundant; most of them explaining the historical journey of the group while few describing its ideological orientation at best. This article would analyze the threat of LeT towards India. The principal questions the article will take includes - What are the LeT's objectives today, and how are they likely to be achieved? What role would the ISI play in LeT's future? How will the LeT work with other groups? And what is likely to be the international pressure on LeT? Answers to these questions are vital for the future security of South Asia.

Immediately after the Mumbai attacks, which is also famous as 26/11 attacks, the US dispatched a team under the leadership of New York Police Commissioner Mr. Raymond Kelly and Under Secretary of Department of Homeland Security Mr. Charles Allen to analyze and provide information on the attacks[7]. Since then the US government has commissioned nearly a dozen of studies to analyze the potential danger from LeT to the US homeland security and US 'interest' abroad[8]. The US government also invited Congressional hearings on this subject from senior defence officials and intelligence personnel. With the submission of dozens of research studies on LeT to the US government and with its subsequent media coverage, there was flooding of research materials on the threat assessment of LeT. Interestingly, all the studies were meant to assess LeT's potential to harm US 'interest' inside and outside America[9]. After the US, almost all leading governments and universities of repute of the world commissioned studies on the Mumbai attacks and LeT with the same perspective - what would be the future potential of LeT to harm 'Western Interest' [10]? Since LeT never attacked any Pakistani interest, there is no such study required or available in Pakistan, which discuss LeT's potential to harm Pakistan in future. Curiously, despite the fact that India is the primary target of LeT, government of India neither employed nor produced any futuristic study on the group. India's intelligentsia is almost silent on this vital subject. There were a few studies conducted by Indian thinktanks after the Mumbai attacks but those were mostly visual spectacles and copy paste job[11]. Whatever little futuristic studies available in India about LeT are only in the domain of newspapers and print periodical magazines. The Indian media has done a commendable job on this subject not only because of their access to information but also because of their commitment to undertake further studies on the LeT[12].

Till the time the article is completed, LeT has never attacked any US target on the US soil. The paintball jihadi, where LeT trained terrorists supposed to attack US targets, never succeeded[13]. Outside the US, LeT never conducted an exclusive attack on any US interest and wherever there was some report of LeT's participation in any attack against US target, the role of LeT was subsidiary in nature[14]. Despite its anger against the US, the group refrained from attacking US interests in the Asian continent[15]. The US views the LeT through the prism of al Qaeda and hence it is paranoid with the very thought of a repetition of $9 / 11[16]$.

Sensing the damaging potential of LeT, especially the organization's public rhetoric on the termination of US supply line towards Afghanistan, an alert US administration placed Hafiz Saeed as one of the 'Most Wanted Terrorists' with a US\$10 million bounty[17]. Wendy R. Sherman, the US under secretary of state for political affairs, announced the reward during a visit to India on April 2, 2012. She also announced a reward of \$2 million for information leading to the capture of Hafiz Abdul Rahman Makki, Saeed's brother-in-law[18]. In the subsequent time, the State Department's announcement became a matter of ridicule as Saeed lives in plain sight in Muridke near Lahore and running his operations from a sprawling compound on the outskirt of Lahore. Immediately after the announcement, Saeed himself appeared live on several television channels deriding the American bounty as a 'foolish step' orchestrated by Pakistan's archenemy, India. He 
said, 'These rewards are usually announced for people who are hiding in mountains or caves. I wish the Americans would give this reward money to me[19].' Experts viewed the US step as a method to place Saeed inside a box as he has been taking out countrywide protests against the resumption of NATO supplies into Afghanistan and drone strikes in Pakistan's tribal area[20].

The reward diplomacy of the US worked rather well. After the announcement, Saeed's well-wishers inside the government 'advised' him to keep low profile and once he was caged, NATO supply lines were resumed[21]. Fearing action from the ISI under US pressure, Saeed went to the Lahore High Court and requested the court 'to direct the government to ask the US to withdraw the bounty and to provide protection to him'[22]. The matter is pending before the court. However, the US remained unfazed. The Secretary of State Hillary Clinton during her India visit reiterated US position that she authorized the 10 million dollar award for the twin objectives of protecting 'US citizens' and 'to go after those who are trying to kill' US citizens[23]. Mrs. Clinton was categorical that the US knows the whereabouts of Saeed and the reward announcement is 'a way of raising the visibility and pointing out to those who are associated with them that there is a cost for that'[24]. Nevertheless, despite the clarification vagueness about the US announcement remained. Meanwhile, Abu Jundal, one of the LeT handlers of Mumbai terrorists resumed his work and in 2009 and in one of the communications Indian agencies heard his plan to attack American and Israeli targets in India. CIA and Mossad were alerted about Jundal's plan[25]. When Abu Jundal was arrested by Indian agencies on June 20, 2012, his interrogation further paranoid the US. Consequentially, the US Treasury Department has placed sanctions on eight leaders of LeT[26].

Contrary to the US paranoia, India has been continuously under attacks from the LeT. Since 1990, nearly $95 \%$ of LeT operations were directed against India[27]. As per the South Asia Terrorism Portal, which list chronologically the attacks conducted by the LeT, there were dozens of LeT attacks on India since November 2008[28]. The most significant terrorist attacks carried out either by the LeT or its proxy since November 2008 were Pune bombing of February 2010, Zavery Bazaar (Mumbai) bombing of July 2011 and Delhi High Court bombing of September 2011[29]. In January 2010, a Mumbai like attacks was replicated in Srinagar's Punjab Hotel, near Lal Chowk where LeT terrorists had holed up and taking constant instruction from their handlers in Pakistan Occupied Kashmir (PoK) during the siege. 'Their communication with their handlers revealed that more attacks are in offing'[30]. These attacks are the testimony of the growing capacity and commitment of LeT to orchestrate deadly terror strike against India. The Lal Chowk siege prompted then union home minister P. Chidambaram to admit that 'the country, especially Jammu and Kashmir, remains vulnerable to militant attacks sponsored by forces from across the border.[31]'

\section{Lashkar-e-Toiba's Growing Clout}

In Pakistan, LeT - the dreaded terrorist organization, has taken a gigantic shape to which even elected government shudder to disturb. High ranking Indian officials admitted that President Zardari and Prime Minister Yousuf Raza Gilani had been confronting difficulty in dealing with groups like LeT[32]. India's worry was added by the fact that the civilian government was incapable of taking action against LeT and the military had not yet made the strategic shift required to do so. During the Kargil War, LeT militants fought along with their army counterpart at the mountains of Kashmir[33]. Immediately after the Kargil defeat, LeT organized a mass rally where LeT Amir Hafiz Saeed addressed the gathering and said, 'We will not rest until the whole of India is dissolved into Pakistan'. He assured his audience that LeT would continue sending militants into India and 'Allah will save them from the fires of hell and huge palaces in paradise awaited those martyred by infidel enemies[34].' There was no demoralizing effect of Kargil defeat on the LeT as the 


\section{Journal of Terrorism Research}

organization promised to send mujahideen into India. Probably this was the reason why Pakistan army paid wages to LeT and sustained the organization[35]. The Army-LeT nexus is especially important as after September 11 attacks, since when most of the militant groups of Pakistan have turned their guns inward and attacked Pakistani interest. LeT is the only group, which has not only refrained from attacking Pakistani interests but also discouraged other groups to do so. Due to its pro-Pakistan ideology and policies, it has deep roots in Pakistani society and military establishment. The robustness of the alliance could be measured from the fact that LeT Commander Zaki-urRehman Lakhvi was still directing LeT operations from custody inside the Adiala Jail. According to a US memo sent to Secretary of State Hillary Clinton and National Security Council, Pakistan Army Chief Gen. Pervez Kayani rejected US request that authorities should take away the cell phone Lakhvi was using in Adiala jail[36].

What is more significant is Jamaat-ud Dawa (JuD); one of the aliases of LeT is no more a banned organization in Pakistan. On November 5, 2011, the interior ministry of Pakistan released a list of 31 banned organizations. LeT is on the list but its changed name $-\mathrm{JuD}$ is missing[37] With renewed support pouring from every conceivable source, LeT is operating with impeccable immunity and posing greater threat to India than ever. Indian army has acquired credible intelligence that the 'LeT is imparting training to 21 selected female terrorists and named the new organization as Dukhtareen-e-Taiba. They are undergoing the training at one of its 42 active training facilities in Muzaffarabad in PoK for carrying out terrorist activities in India[38]'. The raising of female terror group was brainchild of Lakhvi. During the years 2009-2012, security agencies have arrested number of female terrorists in J\&K. The female terrorists are instrumental in sending LeT's messages to its operatives and useful in transporting arms and ammunitions to LeT cadres. They are employed by the LeT to accompany male LeT terrorists by way of camouflaging as their wives, which make the travel of LeT terrorist easy[39]. The group is improvising its skill, performance and adapting to the changing security circumstance with clinical efficiency. With easy and uninterrupted flow of funding (from Saudi Arabia, expatriate Pakistani and ISI), cadres (from Pakistan), weapons and operational guidance (from army and ISI) the group has become the 'civilian extension of Pakistan army[40]', which is consistently on war with India. The LeT is spreading its tentacles with surprising ease. India not only require a superbly vigilant intelligence and quick reaction team but it is indispensable for the country to pre-empt such future threat.

\section{Consolidation of LeT's Threat against India}

The LeT leadership is frank in its appearance in Pakistan and consider its activities as equivalent to that of any political party. After the ban of LeT by the government of Pakistan its spokesman Yahya Mujahid said, LeT's work cannot be stopped by mere ban and when LeT leaders call hundreds of thousands of people gather. He clarified that LeT is not a terrorist organisation but like any other party with political ambitions and support for the Kashmir cause[41]. Saeed make fiery speeches and touches existing political issues of Pakistan. In a speech Saeed said 'Allah has told us to make atom bombs. America is telling us not to. Who should we listen to, oh Muslims, Allah or America? [42]' Immediately after his release in June 2009, Saeed made his public appearance more freequent and took part in political rally including campaign against the Pakistani government's move to repeal the country's controversial blasphemy law[43]. By the time 2011-12, LeT able to work as a political pressure group in a number of areas in central and northern Punjab. Although it openly denounces democracy, it covertly supports candidates of its choice. Saeed openly denounced Pakistan's decision to give India the Most Favored Nation trading status. He warned that 'LeT will surround the markets where Indian goods are sold'[44]. He vowed that jihad to oust Indian forces 


\section{Journal of Terrorism Research}

from Kashmir would continue. The meeting where Saeed speaking was significant. The gathering under the banner of 'Difa-i-Pakistan Conference' was attended by thousands of supporters of Barelvi and Deobandi parties. LeT follows Ahl-al-Hadith brand of Islam to which a minority of Pakistanis, roughly 4 to 5 percent, subscribe. The recognition of LeT by the majoritarian sects like the Barelvi and Deobandi parties and acceptance of its leaders is an indication of future danger. In the coming days LeT would not miss to take centre-stage in Pakistan politics as well and pose danger to the security of India.

The other most important objective of LeT as of 2012 is to unify all militants of Pakistan at the behest of Pakistan army and end the 'current clash of institutions' in Pakistan[45]. The emerging danger to Pakistan today emanates not from its traditional external adversary to the East - India but from homegrown insurgency and militancy[46]. Pakistan army's decision to join US war on terrorism in Afghanistan had turned almost all militant groups of Pakistan against it. After a decade of war, as the US withdrawal from Afghanistan is nearing, Pakistan army again want to realign all the militants of Pakistan and direct them against India and use them to spread Pakistan's influence in Afghanistan. LeT was the only outfit which never opposed Pakistani army. Hence, the Pakistani army is using LeT as a 'Trojan Horse' to bring the rest of the militant groups into its strategic thinking[47]. The Difa-e-Pakistan is a Pakistan army inspired and sponsored organization solely organized by the LeT.

As early as on July 23, 2011, when there was no trace of Difa-e-Pakistan, the LeT organized a gathering in Multan and Hafiz Saeed requested all religious parties and militant groups to unite politically, socially and nationally for the progress of Pakistan. He said 'we need to end all of our internal grievances and work for the greater good.[48]' The new umbrella group Saeed proposed in Multan later became the Difa-e-Pakistan[49]. The group's website is a reflection of LeT's objective. The website counted India's attrocities on Muslim in detail and made India responsible for every single ill of Pakistan. The Difa-e-Pakistan discuss about India's 'Cold-Start' doctrine and India's desire to dominate the region after the US withdrawal from Afghanistan[50]. The army is using Saeed and his LeT to correct its so called mistake committed 10 years before by joining the US war on terrorism. In his address Saeed said, 'The current standoff between state institutions is the result of a sin that we committed 10 years ago by allowing our territory to be used against Afghan Muslims, and until we repent for that grave mistake, we will never be able to overcome these issues[51].'

While disagreements existed in between the civilian government and the army of Pakistan on a range of issues including Kashmir, the LeT's objective is to position itself as close to the army as possible. Denying the role of militant groups like LeT and the use of war as an instrument for the resolution of Kashmir dispute Prime Minister Gilani said, unlike the past century when India and Pakistan fought four wars, it is difficult to afford a war in $21^{\text {st }}$ century. So_dialogue, diplomacy, prudent policy and national consensus must be opted to resolve disputes[52]. However, contrary to the civilian thinking, Gen. Kayani admitted that the ISI maintained contacts with 'certain elements' within the hierarchy of insurgent groups' as 'Pakistan cannot leave both its eastern and western borders insecure'[53]. By aligning the group's objective with the army's strategic vision, LeT has made tremendous progress.

The next objective of LeT is to gather support of rival militant factions and religious parties inside Pakistan[54] and project itself as the flame bearer of Islam. While doing so the group wants to exert greater control on the Pakistani politics and decision-making[55]. As part of mobilizing support from other religious groups of Berelvi and Deobandi bending, LeT has formed the Difa-e-Pakistan and managed to gather over 40 different religious leaders under one platform. Some of the groups 


\section{The Centre for the Study of Terrorism and Political Violence Journal of Terrorism Research}

present along with the JuD at the Difa-e-Pakistan platform like Sepah-e-Saheba Pakistan and Lashkar-e-Jhangvi were earlier opposed to LeT. Although Hafiz Saeed announced that, LeT 'do not have any political aspirations', his intension to influence Pakistani politics is explicit. He said, 'We have a broader perspective of the dangers faced by Pakistan, for that we want to unify the whole nation on a legitimate and focal point of defending the nation against any external aggression and conspiracy'. Answering a question on how can Difa-e-Pakistan influence the policy making and national issues and what does $\mathrm{JuD}$ believe in as an alternate to democratic politics he explained that 'Islam emphasizes on public opinion and the system of Shura does respect the public sentiments and opinions'[56].

\section{Conclusion}

The final objective of LeT, rhetoric (which is 'Nizam-e-Mustafa' or Rule of God)[57] apart, is to use its fame after the Mumbai onslaught and became an international player. Earlier the LeT was resisting the call to enter the Afghan theater of war. However, the aggression and commitment to jihad shown by the several splinter groups in Afghanistan influenced many committed fighters to leave Kashmir centric outfits and join the Taliban category outfits. Infact, the LeT was compelled to consider the spectacular Mumbai strike of 2008 to keep the LeT terrorists out of the ambit of Afghan based militants[58]. Nevertheless, recently the group has shifted its stand and announced that 'Pakistan and Afghanistan were like twin brothers; whoever tried to harm one, would have to face the people of the other country' [59]. This shift of stand is based on two facts; first the US withdrawal is nearing and hence Pakistan want a more pro-active role of militants in Afghanistan and second, LeT has realized the fact that the group cannot remain immune to the development at the western border[60]. As part of this strategy, LeT has reactivated its training camps in Afghanistan[61] and started participating in attacks against Indian targets in Afghanistan[62]. Considering the above background, the present calm in Indo-Pak thaw is a sign of future danger, where Pakistan may use LeT to unsettle India with the explicit intension of resisting India's rise in the region and to restrict India's role in Afghanistan.

About the author: Saroj Kumar Rath, Ph.D is Research Associate at the Graduate School of Law, Hosei University, Tokyo. His research interest is terrorism in India, Pakistan and Afghanistan. His upcoming book 'Fragile Frontiers: The Secret History of Mumbai Terror Attaks' by Routledge Publication is scheduled in 2013.

\section{Notes:}

[1] The News. 2011. 'Mansoor Says Mullen Wanted Zardari's clearance of memo'. November 18.

[2] Confidential Memorandum. Undated. 'Briefing for Adm. Mike Mullen, Chairman, Joint Chiefs of Statt'. (claimed to be sent to Mullen on May 10, 2011).

[3] Ibid.

[4] Rath, Saroj Kumar. 2010. 'New Terror Architecture in South Asia'. India Quarterly. Vol.66, no.4. pp-360.

[5] Ijaz, Mansoor. 2011. 'Time to take on Pakistan's jihadist spies'. Financial Times. October 10.

[6] Ibid.

[7] Allen, Charles. 2009. 'Lessons from the Mumbai Terror Attacks', Testimony before the Senate Committee on Homeland Security and Government Affairs, 8 January. 


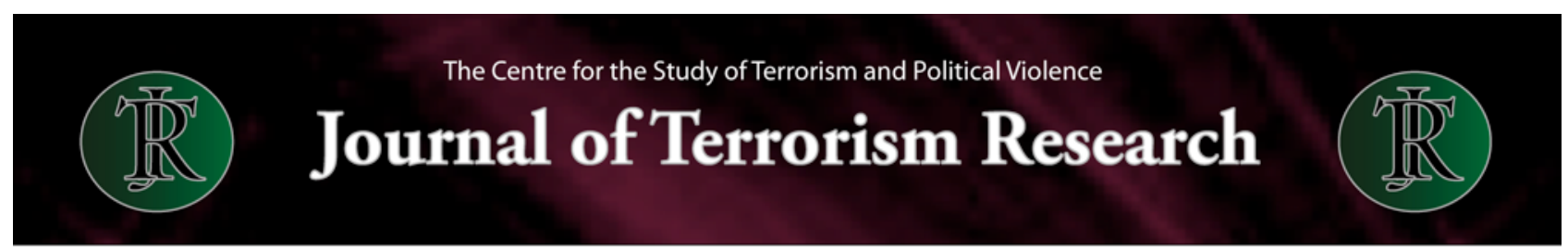

[8] Kronstadt, K. Alan. 2008. 'Terrorist Attacks in Mumbai, India, and Implications for US Interests'. Congressional Research Service Report. December 19; Fair, C. Christine. 2011. 'Lashkar-e-Taiba beyond Bin Laden: Enduring Challenges for the Region and the International Community'. US Senate. Foreign Relations Committee Hearing. May 24; Petreaus, David H. 2010. 'US Senate, Committee on Armed Services'. Washington, DC. June 29; Blair, Denis. 2010. 'Annual Threat Assessment'. February 2; Fair, C. Christine. 2009. 'Implications of the November 2008 Lashkar-e-Taiba (LeT) Attack Upon Several Targets in the Indian Mega-City of Mumbai'; Tellis, Ashley J. 2010. 'Bad Company_Lashkar-e-Taiba and The growing ambition of Islamist Militancy in Pakistan'; Weinbaum, Marvin G. 2010. 'Bad Company: Lashkar-e-Tayyiba.

[9] The mandate of the research studies, as it were all commissioned by the US Government were to assess LeT's capabilities to harm US interest.

[10] Balachandran, Vappala. 2009. 'Dealing with Aftermath of Attack'. Oxford University, UK.; S. Rajaratnam School of International Studies. 2009. 'The 2008 Mumbai Terrorist Attacks'. Nanyang University of Technology. Singapore.

[11] Institute of Defence Studies and Analysis. 2008. 'Terror Strikes Mumbai: The World Reacts'. December 4; Overseas Research Foundation. 2008. 'Mumbai Attacks: Response \& Lessons'; Ghosh, Summerjit. 2008. 'Mumbai Terror Attacks: An Analysis'. Institute of Peace and Conflict Studies. New Delhi.

[12]India Today, Frontline, Outlook, Times of India, The Hindu, Indian Express and Hindustan Times to mention a few.

[13] In early 2002, the LeT was on an overseas buying spree for military equipment through its British operative Abu Khalid. Abu Khalid confessed that he worked with three of the Virginia militants who helped the Briton buy an unmanned airborne vehicle. The Virginia militants were prepared by Cleric Ali al-Timimi of Washington DC, who set up a group to answer Taliban chief Mullah Omar's call to defend Afghanistan against invasion. Virginia residents Randall and Ibrahim, both trained at LeT camps in 2000, began to recruit volunteers on al-Timimi's instructions. All the 12 Virginia jihadis used to play paint ball and hence two of them came up with the idea of using paintball for jihad training after a dinner with Sheikh Ali Timimi. That is how the Jihadi network got the pseudonym Paintball Jihadi. In 2003, while 11 Virginia jihadis were arrested by the FBI in Virginia, one member was held in Saudi Arabia; FBI. 2003. 'USA Vs. Randall Todd Royer', Criminal No.03. June.

[14] Buzby, Mark H. 2008. US Navy Commanding 'Recommendation for Continued Detention'. Department of Defense. Secret File, Naval Station, Guantanamo Bay, Cuba. Source: Wikileaks. April 23.

[15] Blair. Danis. 2010. Op. cit.

[16]Dawn.2011. 'US likens LeT to al Qaeda'. June 3; Fair, C. Christine. 2011. Op. cit.

[17]--------, Rewards for Justice, Seeking Information Against International Terrorism, available at http://www.rewardsforjustice.net/ index.cfm?language $=$ english\&page $=$ saeed .

[18]Declan Walsh, 'US Offers \$10 Million Reward for Pakistani Militant Tied to Mumbai Attacks', The New York Times, April 3, 2012.

[19] Raja, Mudassir and Imtiaz, Huma. 2012. ‘\$10 million reward: Islamabad sees ‘evidence as Hafiz Saeed mocks US bounty’, April 5.

[20] Boone, Jon and Burke, Jason. 2012. 'US offers \$10m reward for Mumbai terror suspect'. The Guardian. April 3.

[21] -----------, 2012. 'Saeed asked to keep low profile, says aide'. Express Tribune. April 24; Schmitt, Eric. 2012. 'Clinton's 'Sorry' to Pakistan Ends Barrier to NATO', New York Times, July 3.

[22] -------. 2012. 'Hafiz Saeed's protection Plea'. Express Tribune. May 8.

[23] Clinton, Hillary. 2012. 'NDTV Exclusive: Hillary Clinton on FDI, Mamata, outsourcing, and Hafiz Saeed'. May 8. NDTV. available at http://www.ndtv.com/article/india/ndtv-exclusive-hillary-clinton-on-fdi-mamata-outsourcing-and-hafiz-saeed-fulltranscript-207593.

[24] Ibid. 


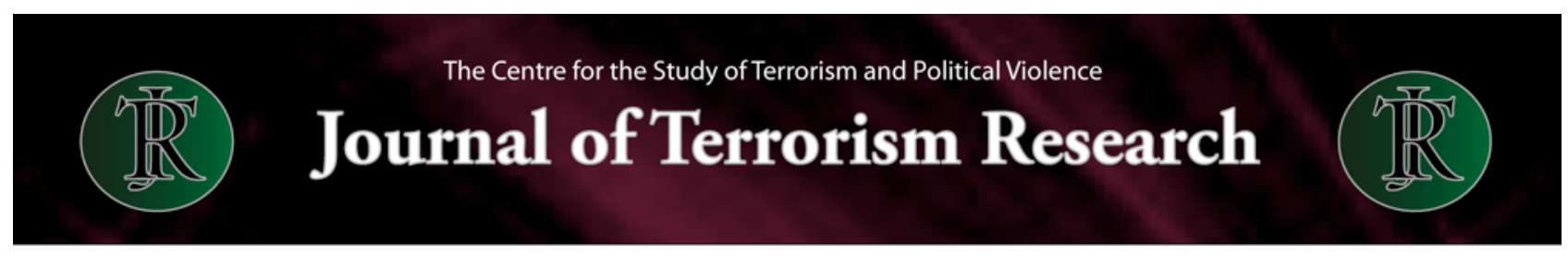

[25] Rath, Saroj Kumar. 2013. From the unpublished manuscript of 'Fragile Frontiers: The Secret History of Mumbai Attacks', New Delhi: SAGE Publication.

[26] The eight persons are Sajid Mir, long time LeT recruiter; Abdullah Mujahid, called LeT's 'senior paramilitary commander for Afghanistan'; Ahmed Yaqub, called LeT's chief for Bangladesh and Nepal operations; Hafiz Khalid Walid, who runs the LeT political bureau; Amir Hamza, a propagandist and central advisory committee member; Qari Muhammad Yaqoob Sheikh, head of the LeT ulema (clerics) wing; Abdullah Muntazir, called an LeT media official, and Talha Saeed, also in teacher and media relations for the group.-----------, 2012. 'US names eight Pakistan LeT militants for sanctions', Dawn, August 30.

[27] LeT participated in few attaks outside India. http://www.satp.org.

[28] South Asian Terrorism Portal. 2012. 'Incident Involving LeT 2008, 2009, 2010, 2011 and 2012'. Available at http:// www.satp.org/satporgtp/countries/india/states/jandk/terrorist_outfits/lashkar_e toiba.htm.

[29] All the three cities and precise places of bombings were scouted by David Coleman Headley; Interrogation Report of David Coleman Headley. 2010. National Investigation Agency. June 10.

[30] Pandit, M Saleem. 2010. 'After 22-hr ops, troops clear Lal Chowk'. Times of India. January 8.

[31] Chidambaram, P. 2010. 'Home Minister Compliments J\&K Police and CRPF for Srinagar Operation'. Ministry of Home Affairs. Press Information Bureau. January 8.

[32] Mulford, David. 2009. 'Menon Tough on Pakistan, Bullish on Bilateral'. US Embassy in New Delhi. Secret Cable. Source: Wikileaks. January 9.

[33] Roggio, Bill. 2009. 'Lashkar-e-Taiba chief again placed under house arrest'. September 21; South Asian Terrorism Portal, Lashkar-e-Toiba. www.satp.com.

[34] Mulford, David. 2006. 'D/NSA supports intel sharing on terrorism; says Terror in south not new but tactics and targets are'. US Embassy in New Delhi. Secret Cable. Source: Wikileaks. January 9.

[35] Mulford, David. 2009. 'Menon Tough on Pakistan, Bullish on Bilateral'. US Embassy in New Delhi. Secret Cable. Source: Wikileaks. January 9.

[36] Rotella, Sebastian. 2011. 'The American Behind India's 9/11 - and How US Botched Chances to Stop Him'. ProPublica. November 22.

[37] Khan, Iftikhar A. 2011. 'New List of Banned Outfits Released'. Dawn. November 6.

[38] Press Trust of India. 2012. 'Lashkar raising 21 female terrorists against India: Army’. Times of India. January 3.

[39]Sethu, Ashok. 2012. 'DIG, BSF Interview with Doordarshan'. February 3.

[40] Shahzad, Syed Saleem. 2011. 'Inside al Qaeda and the Taliban'. London: Plato Publication. pp-86.

[41] Lamb, Christina. 2003. 'Nurseries Of Terror Surge in Pakistan'. The Times. March 30.

http://www.timesonline.co.uk/newspaper/0, 176-628209,00.html.

[42] A taped speech of Hafiz Saeed played on Kashmir Day, at the Jamia Mosque Ghousia, Rawalpindi, February 5, 2002.

[43] Times of India.2010. ‘26/11 mastermind Hafiz Saeed makes public appearance, supports blasphemy laws’, December 16, 2010.

[44] Tanvir, Rana. 2011. 'Hafiz Saeed vows jihad against India will continue'. Express Tribune. December 19.

[45] Raja, Mudassir. 2012. 'Current Situation retribution for allowing our soil’s use against Afghans: Hariz Saeed'. Express Tribune. January 22.

[46] Nawaz, Shuja. 2011. 'Who Controls Pakistan’s Security Forces?'. USIP Special Report 297. December.

[47] The January 22, 2012 rally of Difa-e-Pakistan was attended by former Army Chief Gen. Mirza Aslam Baig and former ISI chief Lt. Gen. Hamid Gul; Difa-e-Pakistan. 2012. 'Defence of Pakistan rally: Govt warned against NATO route restoratioin'. Difa-e- 


\section{The Centre for the Study of Terrorism and Political Violence Journal of Terrorism Research}

Pakistan News. January 24. Available at http://www.difaepakistan.com/news/35-defence-of-pakistan-rally-govt-warned-against-natoroute-restoration-.html.

[48] Raza, Owais. 2011. 'One for all: Jamatud Dawa gathering concludes with a rallying call'. Express Tribune. July 24.

[49] Difa-e-Pakistan was formed in October 2011; Difa-e-Pakistan. 2012. 'About Us'. Available at http://www.difaepakistan.com/ about-us.html.

[50] Difa-e-Pakistan. 2012. 'About Us'. Available at http://www.difaepakistan.com/about-us.html.

[51] Raja, Mudassir. 2012. 'Current Situation retribution for allowing our soil's use against Afghans: Hariz Saeed'. Express Tribune. January 22

[52] Press Trust of India. 2012. 'Pakistan cannot afford war over Kashmir: Prime Minister Gilani'. Times of India. February 6.

[53] Ghauri, Irfan. 2011. 'North Waziristan: US May attack, but they'll think 10 times'. Express Tribune. October 19.

[54] Siddiqui, Taha. 2012. 'Difa-e-Pakistan Part 1.2: Jihadis itch for resurgence'. Express Tribune. February 11.

[55] Saeed, Hafiz. 2012. 'Pakistan's Nukes are the real US target: Hafiz Saeed'. Press Club of Karachi. January 14. Available at http://www.difaepakistan.com/news/32-pakistans-nukes-are-the-real-us-target-hafiz-saeed.html.

[56] Hafiz. 2012. 'Pakistan's Nukes are the real US target: Hafiz Saeed'. Press Club of Karachi. January 14. Available at http:// www.difaepakistan.com/news/32-pakistans-nukes-are-the-real-us-target-hafiz-saeed.html.

[57] The onjective of the outfit is to establish 'Nizam-e-Mustafa'; Interrogation Report of David Coleman Headley. 2010. National Investigation Agency. June 10. pp-14.

[58] Interrogation Report of David Coleman Headley. 2010. National Investigation Agency. June 10. pp-60-61.

[59] Ranveer, Rana. 2011. 'Hafiz Saeed vows jihad against India will continue'. Express Tribune. December 19.

[60] Interrogation Report of David Coleman Headley. 2010. National Investigation Agency. June 10. pp-60-61.

[61] Dorronsoro, Gilles. 2011. 'Afghanistan: The Impossible Transition'. Carnegie Endowment Paper. Washington DC. June. pp-15.

[62] Rubin, Alissa J. 2010. 'Militant Group Expands Attacks in Afghanistan'. New York Times. June 15. 